\title{
Managing Tribalism within Nigeria's Democratic Challenges
}

\author{
Babatunde Oyedeji ${ }^{1}$ \\ ${ }^{1}$ Dept of politics \& international relations, lead city university, Ibadan, Oyo State \\ Correspondence: Babatunde Oyedeji, Dept of politics \& international relations, lead city university, Ibadan, Oyo \\ State. E-mail: tumoxoye@gmail.com
}

Received: September 12, 2017

Accepted: September 27, 2017

Online Published: October 25, 2017

doi:10.5539/mas.v11n11p49

URL: https://doi.org/10.5539/mas.v11n11p49

\begin{abstract}
Tribalism is coined from 'tribes', an alternative word for ethnic or linguistic groups or in some countries 'nation' or 'nationality'. Tribes supply a lot of Nigeria's diversity providing traditional costumes, dress, music, dancing, indigenous language, arts, folklore, religion, all of which can constitute an asset to a people. It is naturally regarded as a small group, a human social organization defined by 'traditions of common descent' having temporary or permanent political integration above the family level with a shared language, culture or ideology. Encyclopedia Britannica asserts that tribe members 'share a tribe name in a contiguous territory, and engage in joint endeavours such as trade, agriculture, house construction, warfare, economic and business activities and warfare. They often stay in small cluster-communities which can grow into large communities and even a nation. This paper attempts to critically examine the multiple play-outs of Nigeria's many tribes and nationalities during and after colonialism, the intricate connection between tribalism and politics, leadership and the evolution of the Nigerian polity, the grievous harm as well as advantages of tribalism to Nigeria's evolution. The tribe is always a major factor in the country and in its people. It ends with specific prognosis and a few recommendations.
\end{abstract}

Keywords: tribalism, ethnicity, federalism, constitution, nationalism

\section{Introduction}

Tribe is often shrouded in negative coloration relevant to societies regarded as underdeveloped, primitive or inferior. It has indeed sometimes become a curse-word, a resented language and a lower-form categorization. The Oxford Dictionary (1980) defined tribal as 'a racial group especially in a primitive or nomadic culture-living as in a community under one or more chiefs'. There is a tendency for human beings to live together in a known natural community. This communal living provides protection, confidence, security, wellness, wholeness and mutuality of consciousness. To Dr Nnamdi Azikiwe, one of Nigeria's original nationalists, every human being is a member of a particular tribe within which are 'customs and traditions established to guide, direct and control the beliefs, attitudes and habits of its individual members' (Azikiwe Nnamdi; 1968;).

There are pejorative descriptions and connotations of tribes, usually it is regarded as a state of being organized or advocating for a tribe in terms of conformity, 'thinking and behaving in which people are more loyal to their tribe than to their friends, their country, or any other social group' a way of being based upon variable combinations of kinship-based organizations, 'a distinct sense of difference by nature of common culture and descent'. It is as powerful as religion in Africa and in Nigeria (Adeyanju G. Colling). It is currently frequently employed derogatively to identify the peoples of Africa and Asia, who were then described as primitive and backward or what most writers in the $19^{\text {th }}$ century used to identify as 'barbaric societies'. Vaaseh (2013) insists that ethnicity is an unfriendly, parochial, spiteful and resentful attitude towards a particular person or harm done to someone else because he or she is of another ethnic group. It is unfortunate that academic disciplines have also popularized this group label. 'Whereas the citizens of a European country are referred to as 'nationalists' of that country, the citizens of Africa are generally referred to as 'native', or successor deprecatory titles like 'negroes', 'blacks', 'slaves', 'defenders' or 'adopted strangers'. Despite the odium of tribalism and ethnicity, it was a common feature of many African countries; "In Rwanda and Burundi, the Hutus and Tutsis struggled for supremacy, in Ghana, the Ewes demanded a reunion with their Kith and Kin in Togo, in Uganda, the subjugation of the Buganda by Obote, in favour of his own group unleashed a complex of hostilities; in the Congo and Nigeria, Kantagese and Ibo attempts at secession led to civil war....". These are apart from forced and violent tribe-driven conflicts in 'Liberia, Somalia, Sudan, Algeria, Angola, Congo, Cameroon, Sierra Leone, Zaire and

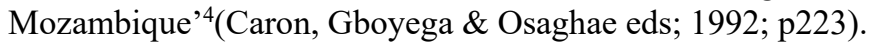


Principal tribes in Nigeria include the Hausa, the Yoruba, the Ibo, the Fulani, the Kanuri, the Tiv, the Ibibio, the Edo, the Nupe, the Annang, the Ijaw, and many others. The three majority tribes -by the 1963 Census- are assumed to constitute up to 57.8 per cent of the national population, to Richard L Sklar ${ }^{5}$, the three biggest tribes of Nigeria, the Hausa with $28 \%$, the Yoruba of the Southwest with $18 \%$ and the Igbo with $14 \%$ of the population share some $60 \%$ of total population, (Agbaje, Diamond \& Nwudiwe eds; 2004) Nigeria's Struggle for Democracy and Good Governance; A Festschrift For Oyeleye Oyediran; Ibadan University Press, p6. There are many groups considered as 'large minorities' and others considered as 'minor minorities' ${ }^{96}$ (Mustapha Abdul Raufu; 2006).

The percentages and proportions bear the caveat of the absence of reputable census figures in Nigeria over the years, '......the bulk of the over 200 -odd minority groups falls into different degrees of "minorities". The percentage of each ethnic groups in the national population is the subject of intense political controversy, particularly among the majority groups and some of the large minorities' (ibid, p.1). The exact magnitude of each tribe has been near-impossible to ascertain, there has been no substantially acceptable census count in the country, there was the problem of claim, counter-claims of ethnic domination, political oppression, marginalization, as between the various ethnic groups in Nigeria. According to Afigbo (1989/4), inter-ethnic rivalry for domination' is a 'fatal affliction' of the Nigerian political process.

The situation was made even more complex by the 1946 division of Nigeria into three regions with the North given $79 \%$ (Momah, 2013) of the entire Nigerian territory and the South being made to share the remaining 21\% which has remained a dangerous albatross stultifying the nation's harmony and unity. The divine right theory has some tribal (even religious) elements to sustain it.

The Drum magazine in Feb 1960 painted a lurid picture 'Tribalism is Nigeria's deadliest enemy'; to the magazine:

"The Nigerian federation is today in very grave danger. For the sake of administrative convenience the country was divided into three major regions-Northern, Eastern and Western. But the immediate danger far outweighs any administrative advantages. That danger is tribalism (ethnicity). And what the danger can do to the unity of the federation, to the spirit of oneness of its peoples, their economic growth , to their sense of civic responsibility and to their tolerance of one another -was amply demonstrated by many incidents during the last general election." (Ottah, 1960).

(Obiozor, 2015) lamented Nigeria as 'an abysmal disappointment in both expectations and achievements' when considered with the socio-economic and political status of India, Brazil, Indonesia. To him, Nigeria was engulfed in the politics of "precarious balancing" in a society of irrepressible pluralism and hostile sub-cultures' in which 'sub-national or ethnic nationalism has dominated and sabotaged all meaningful discussions and debates about national integration and nation-building'. He cited a Nigerian scholar who named Nigeria as one of the 'most and fastest declining states of the world' (Obiozor George; Oct 8, 2015).

\section{Regional Leadership and Tribalism}

Several organizations, personalities and institutions played a major role in the evolution of Nigeria's tribalism especially in starting from the 1947, 1950s and thenceforth. The most important of these persons and organizations are the political parties and the functionaries of the tribes, starting with the largest and most populous part of the country, a claim that has been constantly contested. It was upon the rock of tribalism that the first Republic foundered, tribalism will remain in Nigeria 'a potent centrifugal force and a veritable challenge to statesmanship (Ayandele, 1970). The totality of tribalism was played out in the political and other terrains, 'politics was everything, everything was politics'. Ethnicity as tribalism is often called, produces a constant source of conflict and cleavage. It is commonly ascribed as having its origin in colonialism which forced a direct competitive relationship within the big three tribes causing 'resentment and open hostility'.

The first open display of ethnic chauvinism arose from the Nigerian Youth Movement succession crisis of 1941; to fill the vacancy created by Dr Kofo A Abayomi (who resigned from the Legislative Council), the competition by veteran members Ernest Ikoli and Samuel Akinsanya resulted in 'tension between the Ijaw and the Ijebus' which led to an Ikoli victory and resentment by the Ibos leading to the departure of the Ibos from the Movement. The first Hausa-Igbo clash was in 1945 and was 'sparked off by suspected Igbo ascendancy' (Caron, Gboyega \& Osaghae,1992, p.174-5). Once the genie was let out - into internecine fracas involving bloodshed and bitterness - it has been impossible to contain it over the decades.

\section{Theoretical Foundation}

The 1914 Amalgamation was a forceful marriage of over 350 different ethnic nationalities as one political unit. It 
created a nation polarized by ethnic divide and was done solely for administrative and commercial interests each in the quest to outdo and outplay the other in politics, commerce and relevancy. All units were dominated by fear, suspicion, manipulation for juicy positions and recognition for control of resource and political power, ethnicity was crucial in the formation and development of political parties in Nigeria.

John Lonsdale of Trinity College, (ref $\mathrm{http} / /$ www.google.com/url? sa $=\mathrm{t} \& \mathrm{vct}=\mathrm{j} \& \operatorname{esrc}=\mathrm{s} \&$ source $=\mathrm{web} \& \mathrm{cv}=\mathrm{lsved}=$ OahUKujo) pointed to several classes of theories on 'tribe' including the modernization theorists whom he criticised on the basis that it was wrong to assume that tribalism was present amongst those who were most conservative. Opponents of 'colonial intervention' theory distanced themselves from the claim that colonization was merely for 'divide and rule' strategy since there were positive consequences and contributive measures like enhancing 'ethnic legal traditions', 'inventing standard tribal languages out of a mass of sub-ethnic dialects', encouraged formation of trade unions and cooperatives. There is the false consciousness or ideological manipulation theory which believes that 'African rulers and employers appear to be the patrons of their exploiters of workers and peasants 'as against the true unleasher of exploitation of the peasants. It was also thought that tribalism was a 'form of nationalism' pushing for 'civil rights' comparable to European nationalism. To the extent that the agitation for independence by African and Nigerian nationalists followed examples taken from India and consciousness procured by the $2^{\text {nd }}$ World War as well as ideological influence of the USA in its opposition to slavery and to colonialism, it is pertinent to connect the issue of ethnicity and tribalism in Nigeria to some exogenous factor thus validating the modernization and the nationalism factors to assess tribalism and ethnicity in Nigeria.

Based on the need for multiple nations and groups to develop together, Lenard Binder's Integration theory becomes useful since it attempts a movement towards cohesion and harmony even when integration is irksome, complex and time-taking as in Nigeria, (Folarin, Olanrewaju \& Ajayi, 2012).

Ivo D Duchacek used the term polyethnicity to describe federal systems where territorial units coincide with '......ethnic, tribal, or linguistic' boundaries, (Ivo D Duchacek; 1970; p. 293).Tribalism has no boundaries, it is a universal phenomenon no matter what dignifying coloration and positivity it secures. Events in recent world history have established that "ethnicity is a worldwide social fact and all human beings make their culture within communities that define themselves against others" (John Lonsdale, Moral Ethnicity and Political Tribalism).

\section{Persons and Parties in Tribalism}

The activities of political parties in the last decade pre-independence (1950-1960), the pre-disposition of British colonial masters, the attitudinal fixation of the nationalist political, regional and tribal leaders all coalesced to propel the country into multiple crises one after the other. The crises could not be contained regionally, it spilled over across regions, across tribes, across governments, across the constitutional demarcations engulfing the federal government which was more than willing to take sides whilst seeking to gain from fortuitous temporary but divisive advantage.

With the heated tempo of intense divisions in the Action Group and in the NCNC in the late 1950s and early 60s, the inability of the Balewa-led federal government to muster even a minimum of a peace-broker interventionism and the unwillingness of the leadership of the Action Group to invoke a forgiveness, intra-party reconciliation impetus, the nation suffered the first emergency rule in 1962 and opened the floodgate to what Anthony Enahoro (frontline nationalist of the 50's) called 'the beginning of a chain of events the end of which no one could competently predict'. Nevertheless each region had evinced superior organizational efficiency through its bureaucracy (public administration) so much as was described by Chief Awolowo (as part of his valedictory speech to the Western House of Assembly in 1959 prior to his departure to Lagos to start his incumbency as Leader of Opposition in the Federal House of Representatives):

“...... our civil service is exceedingly efficient, absolutely incorruptible in its upper stratum, and utterly devoted and unstinting in the discharge of its many and onerous duties. For our civil servants, government workers and labourers to bear, uncomplainingly and without breaking down, the heavy and multifarious burdens with which we have in the interest of the public saddled them, is an epic of loyalty and devotion, of physical and mental endurance, and of a sense of mission, on their part. From the bottom of my heart I salute all of them......

(From Chief Awolowo's valedictory speech to the Western House of Assembly, 3 Nov 1959). Thus in Nigeria's Public Administration was always distinct the odious presence of the good, the bad, the ugly. Chief Obafemi Awolowo's own sterling talents were so uniquely outstanding that former British Prime Minister Harold Wilson was quoted as having said “Awolowo's leadership quality could be considered equal to any country in the first world, but he was wasted by Nigeria's Federal system”, (Sowunmi Kunle Zents; 2014; p.69). 
Several phenomena can be grouped as carrying the tag of tribal and divisive instigators that coalesced to push Nigeria towards the precipice. Some of the significant ones:

(a) Although the Northern Peoples' Congress was the dominant political party between 1960 and 1966, it remained unbending in its substantive northern exclusivity, neither changing its name nor seeking active political campaign outside the North. It seemed complacently ensconced having achieved several instances of supportive affection of the British; suspicions of British support towards the 1952/53 Census, the concessions granted to the North after it made an 8-point demand after the aborted Enahoro motion of independence in 1953 and the riots that followed the explanatory campaign move by the Akintola-led delegation to the North. British officials 'dismissed' .....' the Southern educated elite' as 'unreliable, ill-educated, undisciplined, lacking in integrity, self-control and respect for authority of any kind, unfitted to hold posts of trust and responsibility where integrity and loyalty are essential' (Ayandele, Ibid; p.65),

(b) The cumulative effect of the two-party coalition (NPC and the NCNC) constituting the federal government forging a close alliance to impose an intrusion into the Western Region in 1962, tantamount to joining the other political party to crush the Action Group itself the only opposition party in the federal government, (negative aggressions included the judicial probe into the finances of Chief Awolowo and his Action Group lieutenants, the treason trials which saw the Action Group leader in jail and displacement, the creation of the Mid-West State out of the Western Region whilst refusing state creation in much bigger Northern region, the declaration of a state of emergency in the West thus smashing a hedge-hammer to deal decisively with the opposition party whilst ignoring similar crises in other parts of the country, the Tiv and the North Central in particular).

(c) The original models of newspaper ownership in Nigeria was either at inception or soon enough sucked into active partisan politics as were the cases with 'The Record' 1891-1930 of Thomas Horatio Jackson, 'Lagos Daily News' founded by Herbert Macaulay, these papers along with 'Eko Akete' were partisan. So was 'West African Pilot' founded by Dr Nnamdi Azikiwe which was initially 'devoted to promoting serious broad-based anti-colonial mobilization in Nigeria but later became partisan as the mouthpiece of at first the Nigerian National Democratic Party and later the National Council for Nigeria and the Cameroons (Daramola Ifedayo ${ }^{20} ; 2013$ ).

Herbert Samuel Heelas Macauley 1864-1946 trained as professional Engineer in the U K, he was imbued with a strong nationalism and radicalism, was a journalist, musician and politician and was grandson of Bishop Ajayi Crowder. He was strongly opposed to 'an exploitative device by the Home Government to enforce the payment of water rate in 1908'. He was popularly christened 'the Father of Nigerian Nationalism" (Adeniyi Peter; 2010, p 38). He established the first political party in Nigeria, Nigerian National Democratic Party in 1922. The party remained firmly established as exclusive organisation in Lagos only and it competed in the 1923 elections following the Legislative Council set up following the 1922 Clifford Constitution. That Constitution provided for the first recognition in the history of British tropical Africa of the elective principle, as far as Africans are concerned, (Okonkwo; p. 227).

There were several issues that would generate controversies and vitriolic effusions against the colonial government or in defence of the citizens. Examples are the extremely limited democratic/electoral content of the 1922 Clifford Constitution, the preponderance of white colonial officers on the Legislative Council membership, the racial discrimination in the civil service, the exclusion of indigenous qualified Nigerians from positions in the public service and even Church leadership positions and the issue of discrimination in the West and East which led to the Aba and Owerri riots, Calabar and Opobo riots in 1929.

The pre-independence nationalists' fervour was also assisted by the West African Students' Union Movement founded by Ladipo Solanke, WASU was part of largely benign nationalist agitation confined to the search for 'representation on the Legislative Councils to negate the European majority', salary disparity between Europeans and Africans, and the urge for improved educational facilities. The National Youth Movement was founded in 1936 by Samuel Akinsanya, H O Davies, Ernest Ikoli and Dr J C Vaughan in 1936 to replace the Lagos Youth Movement earlier founded in 1934 (Adeniyi, 2010). Another influential catalyst for the incipient nationalist activism was the 'West African Pilot' founded in Lagos by Dr Nnamdi Azikiwe who had shifted from his Accra base to Lagos.

\section{Quota System as Product of Tribalism}

Some scholars have pinned the Nigerian debacle on the contrived territorial predominance and structural imbalance of Nigeria's peculiar brand of federalism. Through the design of Governor Arthur Richards and his 1946 Constitution, he ignored the natural boundaries bequeathed by nature which divided Nigeria into three 
albeit unequal regions, the North with a hefty territory and alleged populace. Governor Richards chose to show the long-standing preference to the North viz-a-viz the Southern Provinces by awarding 77\% to the North, $8.3 \%$ and $8.5 \%$ respectively to the East and the West. The significance of this division is the erstwhile manifestations of preferential decision-making and favouritism constantly conferred on the North as compared to the South, (Ojo, 1998), Empirical Indication of Representation in the Ruling Body 1960-1998. The first major beneficiary of the Quota System was the military. 50\% of military officers were absorbed from the Northern Region, $25 \%$ each from the Eastern and Western Regions (Irikefe, p28). it was designed to ensure more numerical representation of Northerners into the military; regardless of qualifications and competence, the concession was extended to the public service including the education and industrial sectors. Similarly, "Northern region was awarded 174 instead of 92 seats in 1954 in a 320-member legislative assembly, (Meredith, 2005).

Quota for admission into federal higher institutions was later designed to have Merit $40 \%$, States Quota $30 \%$, Catchment Zone $20 \%$ and Discretion 10\%, it also generated constant disquiet in all stakeholders with various criticisms and was later changed to Merit 45\%, Locality 35\% and Educationally-disadvantaged 20\% (Ojerinde, 2009).

The evolution of Nigeria's Steel Industry is one of the saddest victims of the repercussions of tribalism on the pace and twists of development. The project was mooted in 1958, various foreign firms submitted proposals (from the UK, the USA and Germany and the United Nations Industrial Development Organisation, UNIDO) apart from extensive study of raw material availability especially by the Russians. There followed an intense log-jam based on in-fighting by the North and Eastern Regions claiming its greater suitability for the location, Ajaokuta, Aladja, a site in Cross Rivers State, along with various Rolling Mills located in Katsina, Oshogbo and Jos all were eventually involved in '......factionalism, suspicion, nepotism and favouritism.....' The recriminations affected the projects and the personnel, the Ajaokuta project has reportedly guzzled beyond $\$ 15$ billion without tangible results to show, the epic example of tribalism at its worst (Ekeh \& Osaghae, 1989).

The same conflictual bitterness attended the establishment and governance of educational institutions; the early years of the University College, Ibadan, UCI and University of Lagos were afflicted by acute tribalistic competitions involving the highest levels of the leadership of the institutions, the management, teachers and students sometimes violently. In the earlier years of UCI, all effort was made to keep a high standard, indeed 'An unusually large number (in fact about one-third) of the first intake into the university college in 1948 were expelled at the end of the 1948-49 session' as a result of "poor performance" (Ekeh \& Osaghae, ibid, p.54). After a few years of operations, the Inter-University Council IUC had to consider the need for some form of quota for admission of Northerners into the federal universities. As per $1977^{\prime}$ '......the proportion of students from Northern Nigeria in the University College, Ibadan was only 3.6\% while that of women students was 5.5\%'. Along with the 1977 creation of the Joint Admission and Matriculation Board to handle university admissions collectively for the universities, the use of quota for admission into higher institutions has become an important recipe towards redressing the tangle of presumed inequity of opportunities in the institutions. Additional clichés including federal character, educationally disadvantaged, catchment areas, discretion and educationally advanced states come into the equation in competition with merit, to apply in determining states' quotas and claims although there are frequently discontent and agitations by states or citizens. The appointment renewal of a University of Lagos Vice Chancellor created a tribal uproar that led to a major crisis and some threatened bloodshedding in 1962. The same acrimony affected the federal government Corporations including the Railways and the Posts and Telegraphs Departments.

Tribalism was (and is) a major factor in Public Administration, decision-making and day-to-day governance in Nigeria's public service. According to (Ayatse \& Akuva, 2013) ethnicity affected the allocation of federal resources in the first republic, the Hausa-Fulani in charge of administration ensured the allocation of much of the federal funds to the Northern Region as depicted in the following Table:

Table 1. Statutory allocations to regions by central government - 1960/61 - 1965/66 in pounds sterling

\begin{tabular}{llll}
\hline YEAR & NORTHERN REGION & WESTERN REGION & EASTERN REGION \\
\hline $1960 / 61$ & $13,742,087$ & $6,905,153$ & $10,639,928$ \\
$1961 / 62$ & $15,883,229$ & $7,980,715$ & $11,514,427$ \\
$1962 / 63$ & $16,880,556$ & $8,158,291$ & $12,381,302$ \\
$1963 / 64$ & $17,876,906$ & $6,079,699$ & $13,780,873$ \\
$1964 / 65$ & $24,632,836$ & $14,699,196$ & $18,061,945$ \\
$1965 / 66$ & - & $14,461,725$ & \\
\hline
\end{tabular}


Source: Olumide E \& Ekanade T; 2011; "The first Republic and the Interface of Ethnic and Resources Allocation in Nigeria's First Republic" in Afro-Asian Journal of Social Sciences, vol.2, no 2,2011

"Thus, from 1961 to 1966, the Hausa Fulani/NPC, Northern Leadership allocated more funds to the Northern Region than the West and the Eastern Regions. This financial injustice pained the NCNC who were in coalition with the NPC at the Federal Level but could not do otherwise". Ibid

\section{Political Justling Towards Political Independence}

The period between the Clifford Constitution of 1922 and the Richards Constitution of 1946 generated issues that procured creeping attention to regionalism and tribalism. The climate of opinion in the North and that of colonial officers apparently supported the idea of strong regions, this was opposed by another view that the central government in Lagos should be stronger. The movement towards intensified agitation for political independence from British colonialism created some restiveness, suspicion, rivalry amongst the three major tribal groups in Nigeria. There was a struggle for 'recognition' and possible advantage under the British regime (Akpofure \& Crowder; 1966, p.219) ${ }^{29}$. The decade 1950 to 1960 was intensely active for political jostling, group emergence. Some of the erstwhile cultural and social associations; the Bauchi Improvement Union (formed by Malam Abubakar Tafawa Balewa, 1943); the Igbo State Union associated with Dr Nnamdi Azikiwe, the Egbe Omo Oduduwa (formed by Chief Obafemi Awolowo in 1945) became active in the drive to participate in the independence train. The competition amongst the various groups often led to suspicious discussions and unhealthy dialectics, these were the seeds that birthed the first major regional parties that fought for political independence. The Zikist Movement which started with pan-Nigerian and nationalist ideology for a few years collapsed in Feb 1950 when '...... Zikist attempted to assassinate the Chief Secretary to the Government, Hugh Foot. The members were rounded up and two months later, the movement was banned' (Akpofure, ibid, p 222). The first General Election in Nigeria was held in 1951-2, it affirmed the supremacy of the three main regional political parties.

The Igbos are the main ethnic group in south-eastern Nigeria, they have a decentralized and non-hierarchical society, then they are largely Roman Catholic Christians. Discovery of huge scale oil reserves, inter-regional and inter-tribal belligerencies led to military rule and civil war between 1966 and 1970 and subsequent prolonged military rule. These led to intense feeling of marginalization by the Igbos which have not been satisfactorily resolved till now. The tag of Igbo State Union was itself a catalyst to sneer the National Council of Nigeria and the Cameroons as an ethnic political party for only Igbos in Nigeria into the late 1940s (Peter Adeniyi. P 7) ${ }^{30}$ following the examples of the Egbe Omo Oduduwa, the Edo National Union, and the Ibibio National Union all of which helped sow the seeds of discord in Nigeria till today. On his return to Nigeria in 1948, Sir Adeyemo Alakija and Awolowo founded the Egbe Omo Oduduwa which soon after metamorphosed into the Action Group.

The Bauchi Improvement Union in 1949 was supplanted by the Jamiya Matanen Arewa which was transformed into the Northern People's Congress. The cultural organisation declared at its first conference in 1949 its intention to enhance the authority of the natural rulers and help them 'in enlightening the Talakawa'. The gravamen of the philosophy of the party was to emphasise the aspirations of the Northern region and peoples culturally, socially, politically. The Hausa-Fulani are the predominant group in Nigeria's northern Nigeria. It resulted from the wave of Fulani conquests and the adoption of the Hausa Language. Islam is a key component of their ethnic identity and is the basis of their role in Nigerian society and politics. Some eleven of the Northern states adopted the Sharia System of Islamic Law after 1999 which has deepened the tribal chasm and alienation amongst Nigeria's political zones.

\section{Major Issues that Tested Nigeria'S Tribalism 1944-1960 and Beyond}

Following the emergence of three major political parties, (the NCNC in 1944, the AG in 1951 and the NPC in1951), significant issues were happening in the Nigerian territory particularly between the launch of the Richards Constitution in 1946 and the grant of Independence in 1960. Some are worthy of recalling:

Industrial Actions by labour unions with or without political party involvement. The first was a 1945 general country-wide strike called by the 'Railway, Ports, Posts \& Telegraphs workers under Michael Imodu' (Akpofure, Ibid, p 217 $)^{31}$ for $50 \%$ increase in the cost of living allowance and a daily wage of $2 / 6$ for labourers. Seventeen Unions comprising some 30,000 workers went on strike for 37 days. Government had to grant concessions, a commission to examine their grievances was set up (Okonkwo D. Onuzulike; 1964; History of Nigeria; A new Setting, Onitsha, Tabansi Bookshop p. 282). The strike was culmination of some long-nurtured industrial union grievances. Although the Nigerian Government granted 'cost of living allowances' to its workers in 1942, by 1945, the African Civil Service Technical Workers Union demanded an increase in the cost of living allowance, 
consequently, all essential services were disrupted. Government reacted by banning newspapers. The NCNC lent its support to the Strike especially through Dr Azikiwe's daily newspapers, the Strike was ultimately called off when 'the Government appointed a commission to investigate the cost of living in the country' (ibid,). The colonialists even accused Dr Azikiwe of masterminding the strike and the NCNC of complicity.

There was also the Enugu Colliery/Iva Valley Shooting strike that brought about what was later termed the 'Enugu Massacre'. Miners had been encouraged by Zikists to press for the payment of some suspectedly withdrawn arrears of pay. They proceeded on a go-slow and were accused of 'urging people to further riots in Aba, Onitsha, Calabar and Port Harcourt'. Workers concentrated accusations on the white police officer and demanded his return to Nigeria and his trial for mishandling the riots. In Feb, 1950, a Zikist 'attempted to assassinate Hugh Foot Chief Secretary to the Government. Its members were rounded up and the Movement was banned two months later', (Akpofure \& Crowder, p. 221).

After the apparently acrimonious general elections of 1964, the NPC went into a coalition with Akintola's NNDP under whose banner the Federal Education portfolio went to Chief Richard Akinjide who in pursuit of a resolve to redress some perceived injustice done to the Yorubas, had a Federal Scholarship Board release scholarships that were ostensibly more favourable to the Yorubas although to those who were deserving. The same acrimony affected the Federal government Corporations including the Railways and the Posts and Telegraphs Departments. The appointment renewal of a University of Lagos Vice Chancellor created a tribal uproar that led to a major crisis and some threatened bloodshedding in 1962. The renewal of the Vice Chancellorship appointment of Prof Eni Njoku in University of Lagos was disrupted as Prof Saburi Biobaku, first African Registrar of University of Ibadan, was substituted:

"The appointment of Biobaku as VC of Lagos and the blatant prejudice of the Federal Scholarship Board in Sept 1965 in favour of the Yorubas convinced the NCNC that if it did not destroy the NNDP, the NNDP would destroy the NCNC" (Akinjide, 2010).

The Military Coups of 1966.

Perhaps the greatest earthquake against national unity and stability was the military coup of Jan 15 1966. It was carried out by a section of the military but its repercussions have gripped the country since then with scant abatement. Even with apparently the best of intentions, the coup was regarded as a tribal coup aimed at dismantling the socio-political landscape and dislodging the North from its political predominance and substituting a Southern domination or worse still an Ibo domination in a centralized Nigeria. Former President Obasanjo described the causation to the first coup thus:

"The cry and the attitude of political parties and leadership was with selfishness, greed and corruption, sectionalism and tribalism being extolled.......'North for Northerners, West for Westerners, East for Easterners'...... Nobody seemed to care sufficiently for Nigeria as a nation.....there was politics of hatred, division, victimization, destruction, unabashed graft, greed and ostentation"(Obasanjo, 2014; p 169).

An even more gruesome and deadlier revenge coup occurred on $29^{\text {th }}$ July 1966 although its manifestation in terms of killings of Ibo citizens sprawled across May to September 1966. Again it was assumed and adjudged to have been a consciously planned tribal revenge for the January 1966 coup. When a military officer Hassan Katsina was quoted as having said the coups have a way of replicating itself, many more coups, counter-coups, and aborted coups followed along with sanguinary blood-spilling by Nigerian soldiers for tribal and sectional motives.

The Aborted 1993 General Elections.

Another phase of the tribal gymnastics of Nigerian tribes was the peremptory annulment of the results of the well conducted, well respected 1993 general elections. The elections followed a protracted series of manipulated process of capricious rigmaroling by President Babangida who was busy shifting the arrangements and the future of the country at will, till he decided to permit the election to hold but despite its having been successfully conducted, it was only for the military to impugn the integrity of the election for alleged unacceptability of the projected winner MKO Abiola. In any case, most decisions by the military governments left stark suspicions of tribalistic preferences frequently inimical to some tribes, injurious to others, slanted in favour of some. This was particularly true of appointments to top positions in the nation's public service including the military.

Part of the pitfalls ascribed to 1946 Richards Constitution are:

(a) It deviated from the need for national unity as it created three regions and thus strengthened regional autonomy. It excluded universal adult suffrage, the right to vote based on economic status and sex 'only tax payers and males may vote'. It limited direct elections in favour of indirect 
elections. In sum the Constitution -according to Okonkwo -made a mockery of democracy' by vesting in the Governor and Lieutenant Governors, absolute discretion on the right to vote. The powers of the two are unquestionable. Also the legislature was unicameral.

The "coalition of North, East and West in the Council of Ministers made parliamentary democracy meaningless' (Okonkwo, Ibid, 298). Probably the most important catalyst to regional political parties was the McPherson Constitution of 1951 and its fall-outs. After the elections, each of the three regions of the North, the East and West, was controlled and run by different political party mainly supported by the major linguistic group of that region.

The 1946 Richards Constitution effectively completed Governor Bourdillons' 1939 proposal to split the country into three; Governor Richards drafted a full-fledged Constitution thus supplanting the 1922 Clifford Constitution. The aim was primarily ostensibly to promote the unity of Nigeria based on the diverse elements that composed Nigeria and to increase native participation in their own affairs. As lofty as these broad aims were set out, its implementation appeared to have produced diametrically opposite results, disunity, regionalism and separateness. For the first time ever, the Northern Region was brought into the newly created Legislative Council with numerical superiority of representation than the East and the West Regions. Apart from disparate representational arrangements, the Regional Legislative Councils were patently toothless, they could only debate motions, could not propose money resolutions, they were merely deliberative and advisory. To the NCNC, the 'interest of immigrant appointees should not be more paramount over those of indigenous races' (Okonkwo; ibid; p 281). The NCNC resolved to raise funds to send a delegation to London on this issue, they were rebuffed and asked to return to try the Constitution first.

\section{Deficiencies of the 1951 Mcpherson Constitution and Linkage to Tribalism}

\section{NPC Inception and Tribalism}

The very foundation philosophy of the NPC, the ostensibly pan-Nigerian cultural organization Jami-Yyar Mutanen Arewa was 'to enhance the authority of the natural rulers'. The aims of the NPC which emerged in 1951 were that the North would have a common objective, would preserve the traditions and culture of the past, accept the leadership of the NPC with party discipline and loyalty, to seek self-government for Nigeria under a permanent 'Federal Constitution'.

Northern Region'S Resistance to Independence Motion

The 8-point Memorandum by the Northern Legislature (Ajayi Olaniwun ${ }^{35}$; 2012; p 74-5) was a classic handbook for secession-seekers and those currently seeking Nigeria's restructuring:

Each region should have a complete legislative and executive autonomy with respect to all matters except defence, external affairs, customs, and West African Research Institutions,

No central legislative body and no central executive or policy-making body for the whole of Nigeria,

A central agency for all regions to be located in a neutral place i.e. Lagos,

Air services, ports, electricity, and coal mining shall be administered by public corporations,

All revenues shall be levied and collected by the Regional Governments except Customs revenue

Each Region to have a separate Public Service.

\section{Regional Leaders Leading the Tribal Train}

Each of the three regional nationalist independence-seeking tribal leaders extolled his own region's capacity:

Quotes from Chief Awolowo:

"In embracing Western culture, the Yorubas take the lead, and have benefited immensely, as a result. The Efiks, the Ijaws, the Ibibios, and the Ibos come next. The Hausas and Fulanis on the other hand are extremely conservative, and take reluctantly, the Western civilization. And if the race is to the swift, in spite of their lower cultural background, the Ibos or the Ibibios would certainly qualify for self-government, long before the Hausas"36.

Dr Nnamdi Azikiwe in a counter:

'The God of Africa has especially created the Ibo nation to lead the children of Africa from the bondage of the ages.......The martial powers of the Ibo nation at all stages of human history has enabled them not only to conquer others but also to adapt themselves to the role of preserver.....The Ibo nation cannot shirk its responsibility" ${ }^{37}$ (Azikiwe Nnamdi; 1970; p 293). 
Sir Ahmadu Bello was reported to have said:

"The new nation called Nigeria should be an estate of our great grandfather, Uthman Dan Fodio. We must ruthlessly prevent a change of power. We use the minorities in the North as willing tools and the South as a conquered territory and never allow them to rule over us and never allow them to have control over their future'38 The Parrot; 12 Oct 1960; see also Saturday Tribune, 26 Oct 2002, also the Comet, Sat 26 Jul 2003. Similarly, Alhaji Balewa the Prime Minister told the Legislative Council in 1947 “.........We would like the world to know that in the Northern Provinces we have got our own leaders whom we have chosen ourselves, to be our rulers and voices. We do not want, Sir, our Southern neighbours to interfere in our development. If the Southern people feel they are representatives for what they are agitating for and demanding, well they must know that the case of the Northern Provinces is different....but I should like to make it clear that if the British quitted Nigeria now at this stage the Northern people would continue their interrupted conquest to the sea" 39 , (Ayandele, ibid, p106).

The three brilliant regional leaders who founded the major political parties that fought for Independence, had separate ambitions and capacities for themselves, their regions and the nation. Sir Ahmadu Bello preferred to intensify and possibly expand the Sokoto Caliphate hegemony and in any case ensure the solidity of one North that was paramount and dominant in the country also taking the Sardauna of Sokoto title. Thus no concessions were given to acute demands for state creation by northern minorities, the rudiments of equality for women for voting eligibility, even concessions for western education for all were resisted and rejected for long.

Dr Nnamdi Azikiwe was as articulate but not as explicit and dogmatic as Chief Awolowo in the chase for federal structuring based on nationalities, creation of states. Both were focused on securing political independence, both had subtle and implied ambitions to lead Nigeria to independence whilst the Northern Peoples Congress when strongly persuaded to jump on the independence train, preferred freedom on northern terms including a pre-imposed dominance of the country. Whilst the South leaders were fighting for national minorities, regional and national development, Sir Ahmadu Bello focused on northern solidarity and hegemony based on Islam and exclusivity and isolation from the South. This separateness was supported by the British who showered favouritism and deferential preference to northern leaders and Emirs whilst showing contemptuous cynicism to Awolowo and Azikiwe. All three were not focused on taking the unity and progress of Nigeria as a country as a serious matter for collective concern by all.

Tribalism, Ethnicity that were planted between 1940s and 1960s germinated and were reinforced by political behavior after independence and strengthened by emergency rule 1962, treason trial and convictions 1962, census crises 1962 and 1963, federal elections 1964, West Regional elections 1965, the military coup of 15 Jan 1966, the unification decree of May 1966, the revenge coup of 29 Jul 1966, the civil war 1967-1970, the national youth service corps 1973. Palliatives and offered solutions including state and local government creations, constitution-making, 1989, 1995, 1999, federal character principle 1979, all did little to successfully tackle the road to the on-going tribe-based Niger-Delta resistance, the Boko Haram Insurgency, the disfunctionality of Nigeria.

\section{Concluding Phase}

It has been near-impossible for Nigeria to secure a semblance of a reprieve or a renaissance or repeat of the golden era of the 1950s and 60s. Rather, it has fumbled and bungled from one economic, social and political quagmire, retrogression and mediocrity to another; the civil war, prolonged and retardative military rule, endemic injury to minorities and insatiable greed of the majorities, structural adjustment programme, near-crippling indebtedness, an ignorant successive governance leadership, debilitating waste, corruption and want, religious fundamentalist extremism, near anarchy in the minority areas, supreme arrogance by the political leadership accompanied by reckless consumerism.

Two major movements can be ascribed to Nigeria's endemic tragedy, the North with the Caliphate which at heart seeks to turn Nigeria into an Islamic State and probably spread down below Niger and Benue Rivers by 'dipping the Quran into the sea' despite having been checkmated by the Ibadans in Oshogbo in 1843 (Sowumi Kunle Zents; 2014 p.324 $)^{40}$. The second is the inadequate therapy for the minorities whether big or small. Having been seemingly adorned with the divine right to rule accolade, it has been difficult to bring the Northern part of Nigeria to respect the Nigerian Constitution sufficiently viz-a-viz the religion, neither have the minorities learnt to live with a peaceful search for change. President Arap Moi of Kenya has characterized tribalism as a cancer ${ }^{41}$.

${ }^{40}$ Sowumi Kunle Zents; 2014; The Vultures and the Vulnerable, Oriaku \& Okpataku of Nigerian Politics Since $1945 ;$ p.324 
Majority of Africans are unable to forsake their tribe allegiances or channel this tribal energy into a national mainstream. 'Africans are by nature tribalistic', they belong to extended families, a clan, a tribe. In most African nations, one is defined as a citizen only on paper, the primary designation is that of an ethnic group. The schizophrenic and sometimes xenophobic mindset permeate Africa. The central government is viewed often as an outside force that is hostile and irrelevant. In sum, Obafemi Awolowo was dead-on-target with his agitation for a Nigerian federal demarcation based on tribes and nationalities and his repeated demands for state creation in the 50s and 60s (Muzi, 1995).

Despite the thick clouds, it is impossible to ignore the primary advantages of Nigeria's federalism and Nigeria's tribalistic nation; the advantage of size (if well managed), the economy of scale, national and international esteem, the prospects for democracy and development, the patriotism, social modernity all made potentially realizable in a big strong and national entity. However it seems extremely difficult to achieve genuine integration amongst Nigerian tribes:

- The Yorubas blame the Hausa-Fulani for the latter's excessive subservience and collaboration with British colonialists during and after independence,

- The Yorubas also resentfully blame the North's holding on to Ilorin and Kabba instead of allowing both to join the Yoruba states,

- The Yorubas resented the Igbo preference for the North as coalition partners to excise the Mid-West out of the Western Region in 1963 without creating other states,

- The North fears the possibility of collective voting by the East and the West against the North, and so rob them of the predominance bequeathed by colonialists,

- The North always dreaded the prospects of the South swamping their bureaucracy and governance if there is unrestricted access of employment of southerners,

- The East is apprehensive of regaining the lost ground arising from the military coups and the civil war,

- The minorities believe that the majorities would always cheat them so they clamour for $50 \%$ rather than $13 \%$ Derivation.

Each of these constitutes major issues for a Restructuring and Constitutional Re-crafting both of the document and of the minds of the citizenry apart from the appropriate Rupesinghie (1989:9) argument 'For any political system to be responsive to ethnic pluralism and participatory democracy, it must have an economic base that is itself decentralized, self-sustaining and equitable ${ }^{43}$. Tribalism is a perpetual crisis-ocean, a world without end but there is always a point that whatever has a beginning would have an end, so do all wars no matter how long. The wish is to hope that Nigeria would overcome tribalism and secure stability and peace and progress despite itself.

\section{References}

Adeniyi Peter; 2010; Nigeria, Yesterday, Today \& Tomorrow; Ibadan, Daily Graphics Ltd, p 38

Adeyanju, G. C. (7/8/2017). Ethnicity and Tribalism; Welcome to Foresight for Development. Retrieved from http://www.foresight-fordevelopment.org'featured/ethnicity-tribalism.....7/8/2017

Akinjide, O. (2010). Chief S. Ladoke Akintola; His Life \& Times, Ibadan; Mosuro. Publishers, p 173

Akpofore, R., \& Crowder, M. (1966). NIGERIA; A Modern History for Schools; London, Faber \& Faber p. 266,

Awolowo, O. (1947). Path to Nigeria's Freedom, London, Faber \& Faber, p 49.

Ayandele, E. A. (1970). The Educated Elite in the Nigerian Society; Ibadan Univ. Press p 109,

Ayatse, H. F., \& Akuva, I. I. (2013). The Origin and Development of Ethnic Politics \& Impact on Post-Colonial Governance in Nigeria. European Scientific Journal, 19(17), 186.

Azikiwe, N. (1968). Tribalism: A Programmatic Instrument for National Unity. Retrieved from http://www.blackpast.org/1968-nnamdi-azikiwe-tribalism-programmatic-instrument-national-un---6/7/2017

Azikiwe, N. (1970). My Odyssey; An Autobiography; London, C Hurst, p 293.

Caron, B., Gboyega, A., \& Osaghae, E. (1992). Democratic Transition in Africa; CREDU, Inst. of African Studies, Ibadan, p 223,

Daramola, I. (2013). Ethnic Consideration in Political Coverage by Nigerian Media. Kuwait Chapter of Arabian. Journal of Business \& Management, 2(12), 43-45.

Ekeh, P. P., \& Osaghae, E. E. (1989). Federal Character and Federalism in Nigeria; Ibadan, Heinemann 
Educational Books Nig Ltd.

Folarin, S., Olanrewaju, I. P., \& Ajayi, L. Y. (2014). Cultural Plurality, National Integration and the Security Dilemma in Nigeria. Covenant University Journal of Politics \&International Affairs, 2014; 2/1 p.81-92.

Irikefe, P. (2013). Why Nigeria is not Working, the Predicament and the Promise; Ibadan, Kraft Books Ltd, p 28, Isabirye, S., \& Diamini, G. E. (29/4/1995). Tribalism in Africa; the African Global Experience; Muzi.

Ivo, D. D. (1970). Comparative Federalism: The Territorial Dimension of Politics; New York, Holt, Rinehart and Winston, p 293.

John Lonsdale of Trinity College, Cambridge. Retrieved from http://www.google.com/url? sa=t\&vct=j\&esrc=s\&source=web\&cv=lsved=OahUKujo

Meredith, M. (2005). The Fate of AFRICA, A History of the Continent since Independence. NY Public Affairs p. 75.

Momah, S. (2013). Nigeria Beyond Divorce; Amalgamation in Perspective; Ibadan, Bookcraft, p 13,

Muzi, O. G. E. (30/Apr1995). The African Global Experience: Tribalism in Africa. Retrieved from http://www.hartford-hwp.com/archives/30/065.html

Obasanjo, O. (2014). My Watch, Early Life and the Military; Lagos, Prestige p. 169.

Obiozor, G. A. (Oct 8, 2015). Nigerian Politics Leadership and Nation Building; African Sun Times; $9^{\text {th }}$ of June 2017.

Ojerinde, D. (2009). Using Assessment for the Improvement of Tertiary Education in Nigeria: the Joint Admission \& Matriculation Board Role.

Okonkwo, D. O. (1964). History of Nigeria in a New Setting; Onitsha, Tabansi Bookshop ibid p 265.

Olaniwun, A. (2012). Nigeria: Africa's Failed Asset; Ibadan, Bookcraft; p 37.

Ottah, N. (Feb 1960). Tribalism is Nigeria’s Deadliest Enemy; Drum Magazine, 191.

Rupesingh, K. (1989). Internal Conflicts and their Resolution; the Case of Uganda, in his ed, Conflict Resolution in Uganda in Coren, Gboyega \& Osaghae eds, ibid, p. 234.

Sklar, R. L. (1963). Nigerian Political Parties; Power in an Emergent African Nation, Princeton Univ Press. Mustapha, A. R. (2006). Ethnic Structure, Inequality, \& Governance of the Public Sector in Nigeria, UN Research Inst for Soc Development, Programme Paper 24, Nov 2006,

Sowumi, K. Z. (2014). The Vultures and the Vulnerable, Oriaku \& Okpataku of Nigerian. Politics Since 1945, p 324.

Sowunmi, K. Z. (2014). The Vultures and the Vulnerable, Oriaku and Okpataku of Nigerian Politics since 1945; Brooklyn NY, Korloki Publishing Co., p. 69,

The Parrot; 12 Oct 1960; Saturday Tribune, 26 Oct 2002, the Comet, Sat 26 Jul 2003.

Vaaseh, G. A. (2013). Ethnicity, Conflicts, and the Rise of Militia Groups in Nigeria, in Ndiove-Gatsheni, S J \& Mhlanga B eds; Bondage of Boundarie and Identity Politics in Postcolonial Africa.

\section{Copyrights}

Copyright for this article is retained by the author(s), with first publication rights granted to the journal.

This is an open-access article distributed under the terms and conditions of the Creative Commons Attribution license (http://creativecommons.org/licenses/by/4.0/). 